NBER WORKING PAPER SERIES

\title{
TELEMIGRATION AND DEVELOPMENT: ON THE OFFSHORABILITY OF TELEWORKABLE JOBS
}

\author{
Richard Baldwin \\ Jonathan I. Dingel \\ Working Paper 29387 \\ http://www.nber.org/papers/w29387 \\ NATIONAL BUREAU OF ECONOMIC RESEARCH \\ 1050 Massachusetts Avenue \\ Cambridge, MA 02138 \\ October 2021
}

We thank Linghui $\mathrm{Wu}$ and Ka Lok (Steve) Wong for excellent research assistance, Kari Greenswag for helpful editorial assistance, and Gene Grossman and Thomas Sampson for valuable feedback. This paper was prepared for the book project, AI/Robots: Labour, Trade, Growth and Welfare, edited by Lili Yan Ing and Gene Grossman for the Economic Research Institute for ASEAN and East Asia (ERIA) in Jakarta. Dingel thanks the Cohen and Keenoy Faculty Research Fund at the University of Chicago Booth School of Business. The views expressed herein are those of the authors and do not necessarily reflect the views of the National Bureau of Economic Research.

NBER working papers are circulated for discussion and comment purposes. They have not been peer-reviewed or been subject to the review by the NBER Board of Directors that accompanies official NBER publications.

(C) 2021 by Richard Baldwin and Jonathan I. Dingel. All rights reserved. Short sections of text, not to exceed two paragraphs, may be quoted without explicit permission provided that full credit, including $\odot$ notice, is given to the source. 
Telemigration and Development: On the Offshorability of Teleworkable Jobs

Richard Baldwin and Jonathan I. Dingel

NBER Working Paper No. 29387

October 2021

JEL No. F1,J2

\begin{abstract}
$\underline{\text { ABSTRACT }}$
The Covid-19 pandemic has introduced huge numbers of employers and employees to remote work. How many of these newly remote jobs will go overseas? We offer a rough quantification based on two observations: 1) offshore work is trade in services, and 2) the number of telemigrants is the volume of this trade divided by the average wage. Combining these with gravity-model estimates, we can roughly predict the number of new telemigrants that would arise from lower barriers to trade in services. Telemigration seems unlikely to be transformative when it comes to the development paths of most emerging economies. The baseline service trade flows are modest, and the standard gravity model restricts modest changes to have modest impacts. There are no tipping points in structural gravity models. Finally, we propose a simple model of telemigration in which small changes can have large consequences. The key is to assume that latent comparative advantage takes a different shape than typically assumed in quantitative trade models. Given this, small changes in trade costs can generate large and asymmetric increases in the exports of service tasks from low-wage nations.
\end{abstract}

\author{
Richard Baldwin \\ Pavillard 6 \\ CH-1009 Pully \\ SWITZERLAND \\ and CEPR \\ and also NBER \\ rbaldwin@cepr.org \\ Jonathan I. Dingel \\ Booth School of Business \\ University of Chicago \\ 5807 South Woodlawn Avenue \\ Chicago, IL 60637 \\ and NBER \\ jdingel@chicagobooth.edu
}




\title{
Telemigration and development: On the offshorability of teleworkable jobs
}

Richard Baldwin (Graduate Institute, Geneva) and Jonathan I. Dingel (University of Chicago, Booth School of Business) $)^{1}$

October 2021

\begin{abstract}
The Covid-19 pandemic has introduced huge numbers of employers and employees to remote work. How many of these newly remote jobs will go overseas? We offer a rough quantification based on two observations: 1 ) offshore work is trade in services, and 2) the number of telemigrants is the volume of this trade divided by the average wage. Combining these with gravity-model estimates, we can roughly predict the number of new telemigrants that would arise from lower barriers to trade in services. Telemigration seems unlikely to be transformative when it comes to the development paths of most emerging economies. The baseline service trade flows are modest, and the standard gravity model restricts modest changes to have modest impacts. There are no tipping points in structural gravity models. Finally, we propose a simple model of telemigration in which small changes can have large consequences. The key is to assume that latent comparative advantage takes a different shape than typically assumed in quantitative trade models. Given this, small changes in trade costs can generate large and asymmetric increases in the exports of service tasks from low-wage nations.
\end{abstract}

\section{Introduction}

The future of globalisation is changing for one ineluctable reason. The cost of moving weightless things (ideas and data) is falling radically faster than the cost of moving heavy things (goods). Telemigration - namely, working from home when home is abroad - is a small but fast-growing aspect of globalisation's weightless future.

Will telemigration have a measurable impact on development? The answer to this question turns on the answer to a second question: How many service-sector jobs will be offshored from rich nations to emerging markets? Since answering this requires all sorts of unknowable things, economists have tended to focus on a narrower question: How many jobs are offshorable?

More than a decade ago, Alan Blinder (2007) tackled the narrower question by looking at features of jobs in the United States. His answer was based on two vectors. The first vector described the offshorability of each occupation. The second vector was the number of US workers employed in each occupation. The inner product of these vectors yielded the number of US jobs that could be offshored. Blinder's answer was: "I estimate that somewhere between $22 \%$ and $29 \%$ of all US jobs

\footnotetext{
'We thank Linghui Wu and Ka Lok (Steve) Wong for excellent research assistance, Kari Greenswag for helpful editorial assistance, and Gene Grossman and Thomas Sampson for valuable feedback. This paper was prepared for the book project, AI/Robots: Labour, Trade, Growth and Welfare, edited by Lili Yan Ing and Gene Grossman for the Economic Research Institute for ASEAN and East Asia (ERIA) in Jakarta. Dingel thanks the Cohen and Keenoy Faculty Research Fund at the University of Chicago Booth School of Business.
} 
are or will be potentially offshorable within a decade or two. (I make no estimate of how many jobs will actually be offshored.)" ${ }^{2}$

One goal of this paper is to argue that moving from the narrow question to the broader question should involve switching from a focus on the nature of occupations to broader considerations that point to the gravity equation as a way of roughly quantifying the value of work that might be offshored to workers in lower-wage economies. We develop the exercise in Section 3 (theoretical motivation) and Section 4 (quantification exercise).

The conclusion of our rough quantification exercise is that telemigration is starting from too low of a base to allow it to become a major force for development - unless something radical changes. The constant-elasticity gravity model we employ embeds a series of assumptions that limit the impact of modest declines in trade costs. Correspondingly, telemigration should not be much of a threat to the service workers in high-wage nations. This soothing conclusion flies in the face of the anxiety that online offshoring evokes in high-wage nations. For example, David Wessel (2004) wrote in The Wall Street Journal: "Much of the American anxiety about outsourcing to India and China can be boiled down to this simple question: Will there be good jobs left for our kids? ... Tens of millions of increasingly skilled Chinese and Indian workers are joining the global economy at a moment when technology can dispatch white-collar work overseas almost instantly."

What is the source of this mismatch between popular perceptions and our quantification exercise? Is the model we are using missing something, or does the popular anxiety reflect the familiar disconnect between trade economists and the public regarding the role of comparative advantage in general equilibrium? In Section 5, we explore the possibility that the mismatch might be the fault of the model.

Canonical frameworks rule out the possibility that modest changes in trade frictions can generate radical changes in employment patterns. Quantitative Ricardian trade models, starting from Eaton and Kortum (2002), typically assume that the pattern of comparative advantage is symmetric across countries. ${ }^{3}$ More broadly, quantitative trade models typically feature a constant trade elasticity, so that the direct effect of a symmetric decline in trade costs is a symmetric increase in exports by both high- and low-wage nations.

In Section 5, we articulate circumstances that allow marginal changes to have radical effects. The analytic framework features both trade in goods and telemigration, which is trade in services. In this simple two-country model of telemigration, a symmetric decline in the costs of trading services internationally can have very asymmetric consequences for the exports of developed and developing economies. The key is to assume that latent comparative advantage takes a different shape than typically assumed in quantitative trade models. In short, it is a model in which telemigration could meaningfully shape low-wage nations' development journeys, with attendant effects on the servicesector employment prospects of workers in high-wage economies. ${ }^{4}$

\section{Offshored jobs: Beyond the two-vector approach}

Blinder's seminal calculations turned primarily on his judgement of the offshorability of particular occupations using a four-way categorisation that ranged from non-offshorable (Category IV) to highly offshorable (Category I). The judgement was guided by a decision tree illustrated in Figure 2.1.

\footnotetext{
The quotation is from the abstract of Blinder (2007). The paper was published as Blinder (2009).

In Eaton and Kortum (2002), productivity follows a Fréchet distribution. This distribution's location parameter, which governs absolute advantage, is country-specific. Its shape parameter, which governs comparative advantage, is common across countries.

${ }^{4}$ The possibility of a disruptive outcome is the focus of Baldwin (2019).
} 


\section{Figure 2.1: Blinder's classification procedure.}

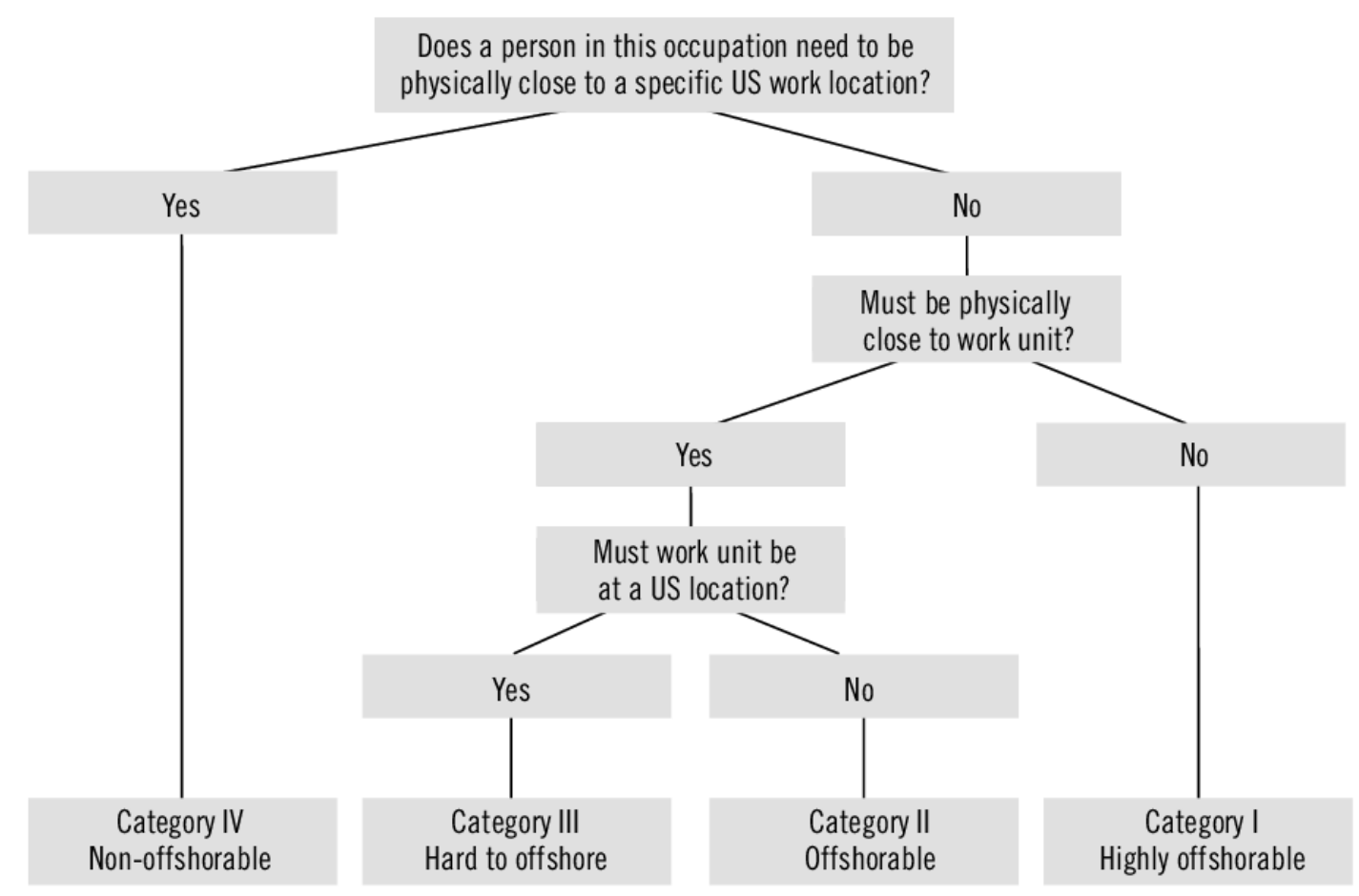

Source: Blinder (2007).

These judgements were then matched with the number of US workers employed in the relevant occupations. The two vectors he used are shown in Table 2.1. The calculation was done under a "conservative" assumption - scenario Low in the table - that includes all jobs in category I and II occupations, and an "aggressive" assumption - scenario High in the table - that also includes all category III occupations. The inner product of the low scenario vector and the jobs vector yields the answer that about 29 million jobs are offshorable, which was about $22 \%$ of the labour force in 2004. The inner product of the high scenario vector with the jobs vector gives the answer that about 38 million jobs might be offshorable (about $29 \%$ of all jobs). Blinder refined the first vector, which describes the offshorability of each occupation, in subsequent research (Blinder 2009; Blinder and Krueger 2013).

Some researchers came up with broadly similar results, while others found much lower figures. McKinsey Global Institute (2005) looked at eight representative sectors in various high-wage economies and estimated that about $11 \%$ of the jobs were offshorable to developing countries. Bardhan and Kroll (2003) found that about $11 \%$ of all US jobs were offshorable, but they limited themselves to occupations where some offshoring was already occurring. Van Welsum and Vickery (2005) gauged that $20 \%$ of total US employment was offshorable. Jensen and Kletzer (2010) used a very different approach that leveraged location data inside the US. Geographically concentrated service sectors were more tradable, they suggested, because service consumers tend to be dispersed in proportion to the population. Their work implied that $38 \%$ of US workers are in tradable, and therefore offshorable, occupations. In brief, the estimates were never negligible, but some were less than half those of Blinder's original estimate. 
Table 2.1: Major Occupations Ranked by Offshorability Score (OS)

\begin{tabular}{|c|c|c|c|c|}
\hline \multirow[t]{2}{*}{ Occupation } & \multirow[t]{2}{*}{ OS } & \multicolumn{2}{|c|}{ Scenarios } & \multirow[t]{2}{*}{ Workers } \\
\hline & & Low & High & \\
\hline Computer programmers & I & 1 & 1 & 389,090 \\
\hline Telemarketers & I & 1 & 1 & 400,860 \\
\hline Computer systems analysts & 1 & 1 & 1 & 492,120 \\
\hline Billing and posting clerks and machine operators & I & 1 & 1 & 513,020 \\
\hline Bookkeeping, accounting, and auditing clerks & 1 & 1 & 1 & $1,815,340$ \\
\hline Computer support specialists & I and II & 1 & 1 & 499,860 \\
\hline Computer software engineers, applications & II & 1 & 1 & 455,980 \\
\hline Computer software engineers, systems software & II & 1 & 1 & 320,720 \\
\hline Accountants & II & 1 & 1 & 591,311 \\
\hline Welders, cutters, solderers, and brazers & II & 1 & 1 & 358,050 \\
\hline Helpers-production workers & II & 1 & 1 & 528,610 \\
\hline $\begin{array}{l}\text { First-line supervisors/managers of production and operating } \\
\text { workers }\end{array}$ & II & 1 & 1 & 679,930 \\
\hline Packaging and filling machine operators and tenders & II & 1 & 1 & 396,270 \\
\hline Team assemblers & II & 1 & 1 & $1,242,370$ \\
\hline Bill and account collectors & II & 1 & 1 & 431,280 \\
\hline Machinists & II & 1 & 1 & 368,380 \\
\hline Inspectors, testers, sorters, samplers, and weighers & II & 1 & 1 & 506,160 \\
\hline General and operations managers & III & & 1 & $1,663,810$ \\
\hline Stock clerks and order fillers & III & & 1 & $1,625,430$ \\
\hline Shipping, receiving, and traffic clerks & III & & 1 & 759,910 \\
\hline Sales managers & III & & 1 & 317,970 \\
\hline Business operations specialists, and all others & IV & & & 916,290 \\
\hline
\end{tabular}

Source: Authors' elaboration of information in Blinder (2007), Table 2.

\subsection{The two-vector approach}

Last year, Dingel and Neiman (2020) took a two-vector approach to answer a question that seems similar to Blinder's: how many jobs can be done at home? Using job traits from the Occupational Information Network (O*NET) survey, they built the first vector by classifying each occupation as able to be performed remotely or not. The second vector, as with Blinder, contained the number of people working in the corresponding occupations. The inner product of the two provided the answer to the question.

But the Dingel-Neiman and Blinder questions differ in subtle but important ways. Dingel and Neiman (2020) asked how many workers could sit in their homes during the pandemic and perform the same job they were (overwhelmingly) performing at their employers' offices prior to the pandemic. Quite obviously, the main issue is the nature of the jobs: can they be performed remotely? The nature of the workers is irrelevant as far as teleworkability is concerned because the exercise considers whether the same workers could do the jobs from home.

Blinder (2007) answered a very different question. He asked whether, for example, a Uruguayan political analyst could do the same job as an American political analyst by exporting the service to US customers currently serviced by that American analyst. Here both the nature of the job and the nature of the workers would seem to matter: can the service be provided from another country and are there foreign workers who can provide it? Note that Blinder (2007) explicitly recognises the point, "the task is to estimate the number of jobs that are potentially offshorable, meaning that Americans performing those jobs face potential competition from, say, Indian or Chinese workers." 


\subsection{Additional considerations}

Whether an "offshorable" job (in the sense of Blinder 2009) is actually performed offshore depends on a number of other considerations. First, there must be foreign workers who are capable of doing the work. We would want to incorporate data that speaks to the number of potential foreign suppliers in each occupation. Occupations that can be performed remotely tend to be skill-intensive, high-wage jobs in the United States (Dingel and Neiman 2020). As Blinder (2006) discussed, this is part of the concern about the labour-market consequences of emerging markets exporting such services to developed economies. It also means that the potential foreign suppliers are not the total foreign labour force but the number of foreign workers who possess the relevant skills, as revealed by, for example, educational attainment or current occupation.

Second, one must address the fact that domestic and foreign workers are still not perfect substitutes even when they have the same level of educational attainment or occupational title. For example, English-speaking Canadians might be pretty good substitutes for English-speaking Americans in many teleworkable jobs, but Portuguese-speaking Brazilians seem less likely to be able to immediately perform the relevant language-intensive tasks. Even English speakers from different countries may find that their interactions with customers and co-workers are subject to a variety of linguistic and cultural frictions, as captured by the quip that the United States and Great Britain are two countries separated by a common language.

\section{Figure 2.2 Importance of English language for teleworkable versus non-teleworkable jobs}

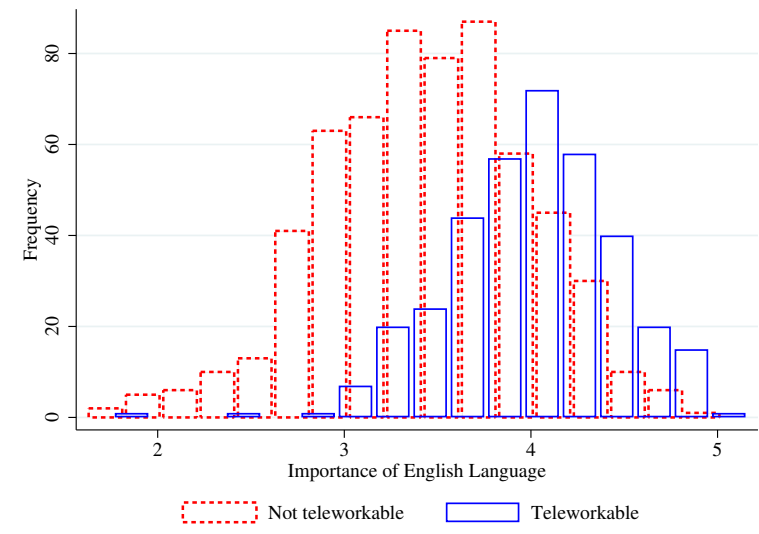

Source: Authors' elaboration of $O^{*} N E T$ data. The classification of occupations as teleworkable or not is from Dingel and Neiman (2020).

As it turns out, such frictions may be particularly relevant in the kinds of occupations that can be performed remotely. The O*NET surveys that Dingel and Neiman (2020) used to classify occupations as able to be performed remotely also characterize the language intensity and importance of soft skills in each occupation on a scale from 1 to 5 . Figure 2.2 shows that teleworkable occupations place much greater importance on command of the English language than those occupations that cannot be performed remotely. The occupation with the highest importance of English language score is public relations specialist (4.96 out of 5 ). While this job can be performed remotely, it also is an occupation in which linguistic nuance and precision are very important. 
Figure 2.3: Importance of oral and written expression for teleworkable versus nonteleworkable jobs
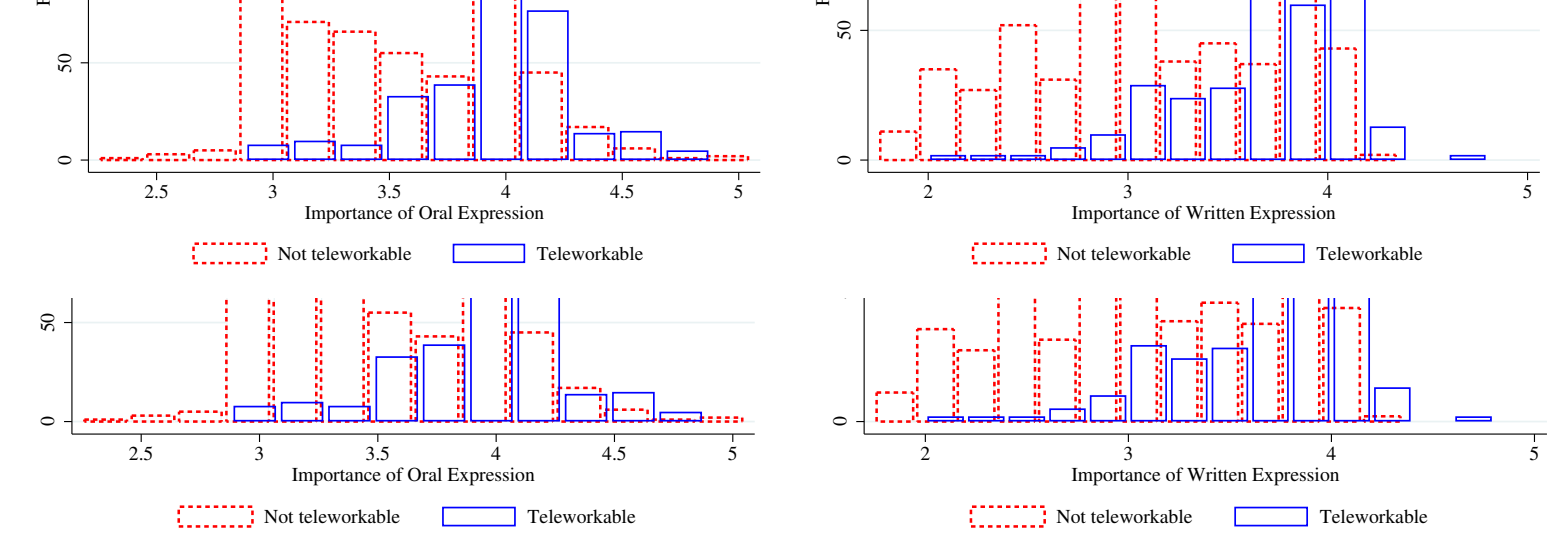

Source: Authors' elaboration of $O^{*} N E T$ data. The classification of occupations as teleworkable or not is from Dingel and Neiman (2020).

Figure 2.4: Importance of persuasion and social perceptiveness for teleworkable versus non-teleworkable jobs
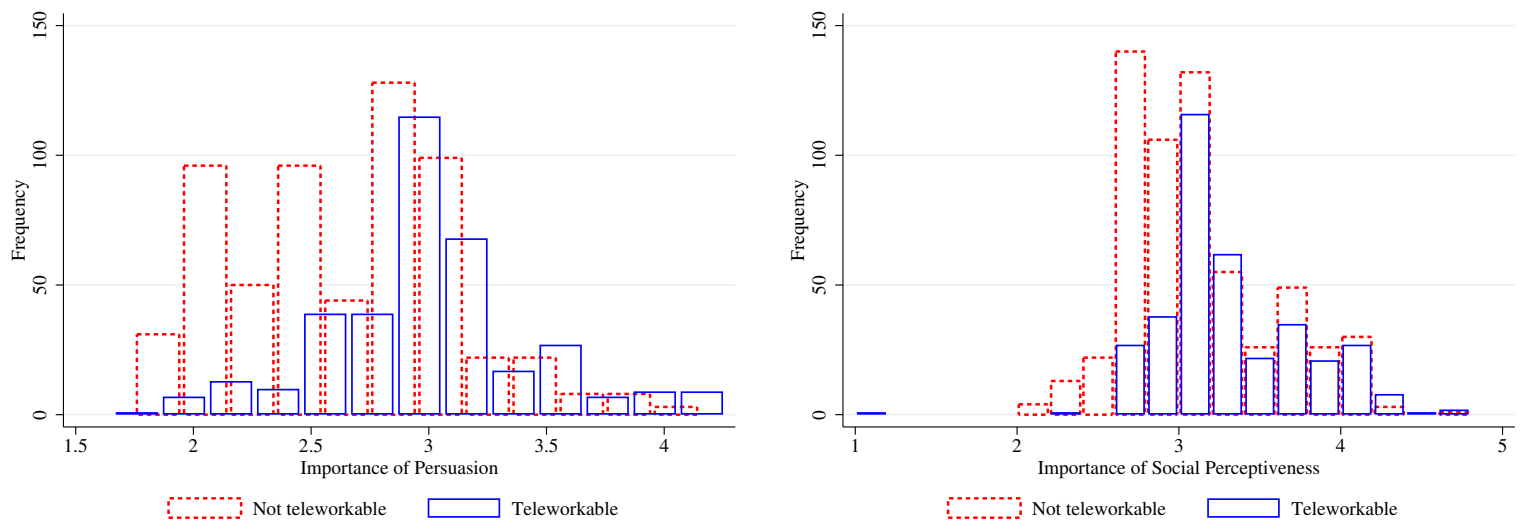

Source: Authors' elaboration of $O^{*} N E T$ data. The classification of occupations as teleworkable or not is from Dingel and Neiman (2020).

More broadly, jobs that can be done remotely tend to rely on soft skills, which embed elements that are specific to particular social and cultural contexts. Deming (2017) documents a rising return to social skills in the United States in recent decades and emphasizes that the fastest growing cognitive occupations have been those requiring significant interpersonal interaction. As shown in Figure 2.3, jobs that can be done remotely are also occupations that typically place greater importance on oral expression and written expression. Figure 2.4 shows that teleworkable jobs also typically place greater importance on persuasion and social perceptiveness. Both sales engineers and mathematical technicians can telework, but they are at opposite extremes in terms of the importance of persuasion ( 4.25 versus 1.66 out of 5). To the extent that social and cultural contexts vary across countries, this makes it less likely that a public relations specialist or a sales engineer located in Hanoi is a perfect substitute for one located in Seattle.

\subsection{CAGE distance}

One way to articulate the question about the substitutability of workers from different linguistic, cultural, and social contexts is to view it as a matter of "distance" between workers. The metaphoric 
distance encompasses a variety of dimensions. For example, activities that can be performed remotely but must be performed synchronously will be sensitive to differences in time zones (Bahar 2020). Considering pairs of countries, Ghemawat (2007) dubs differences in these cultural, administrative, geographic, and economic factors the "CAGE" distance between them. In this sense, French-speaking Canadians in Quebec can be considered "farther" from New York employers than English-speaking Canadians in Calgary, even though Calgary is over 3000 kilometres farther away.

This framing of the substitutability between domestic and foreign workers as a bilateral distance leads immediately to a standard concern in trade - the existence of alternative suppliers. The likelihood of US firms hiring foreign workers from a given country depends not just on the bilateral CAGE distance to that country, but also on the bilateral distances to alternative sources of workers.

Thus, in addition to the two-vector approach that estimates the mass of teleworkable jobs in one nation that might be supplied from abroad, one should consider the mass of potential suppliers in other nations and a measure of "distance" between the two. In moving from the question of "how many developed-economy jobs are offshorable?" to "how many developed-economy jobs could go offshore to emerging markets?", we have added considerations about the exporting nation's economic mass and bilateral impediments to such potential trade in services. That points to the gravity equation for international transactions, a long-standing means of summarizing the expected volume of trade between economies.

\subsection{Gravity is a hard habit to shake off}

The simplest gravity equation predicts that bilateral trade in goods will be proportional to the economic mass of the origin nation times the economic mass of the destination nation divided by the bilateral distance (Head and Mayer 2014). In thinking about occupation-level transactions, one would need the demand for teleworkable tasks in the importing nation, a measure of potential supply in the exporting nation, and a notion of distance. The tally of jobs in the importing nation that can be performed remotely is the relevant importer mass, the population of suitably skilled workers is the relevant exporter mass, and various "CAGE" distances capture bilateral trade frictions.

As it turns out, estimation using importer and exporter fixed effects addresses the role of competing alternative suppliers and obviates the need to gather data on the mass variables, albeit at the cost of restricting thought experiments about potential supply. Before getting there, it is worth being explicit about how we are thinking about telemigration as trade in services in the context of the gravity equation.

\section{A first-pass gravity equation for telemigration}

To guide our thinking about using gravity to study telemigration, it is useful to lay out the steps in the model's simplest derivation. Here we sketch the gravity model in which all economic activity is in the service sector. This one-sector exposition follows Baldwin and Taglioni (2006).

Suppose that each potential telemigrant provides nationally differentiated labour services (the Armington assumption). ${ }^{5}$ Workers in nation $o$ ("origin") charge a price in market $d$ ("destination") of pod. The export of services from workers in nation $o$ to nation $d$ is:

$$
p_{\text {od }} x_{o d} \equiv \text { share }_{o d} E_{d}
$$

\footnotetext{
s The assumption that workers in different nations produce imperfect substitutes is merely a convenient shortcut to obtain a constant-elasticity gravity equation. The substantive assumption is that the aggregate import demand system is CES. For example, Eaton and Kortum (2002) provide a Ricardian model in which workers in different nations compete to produce the same set of goods that yields a constant-elasticity gravity equation.
} 
where share $e_{o d}$ is the share of expenditure in market $d$ on services supplied by workers in $o$. $E_{d}$ is total expenditure on teleworkable jobs in nation $d$. Next, we link shares to relative prices using a CES demand function:

$$
\text { share }_{o d}=\left(\frac{p_{o d}}{P_{d}}\right)^{1-\sigma}, \text { where } P_{d}=\left(\sum_{k=1}^{R}\left(p_{k d}\right)^{1-\sigma}\right)^{1 /(1-\sigma)}, \sigma>1
$$

where $R$ is the number of nations in the world. Assuming perfect competition, the equilibrium price is

$$
p_{o d}=\tau_{o d} w_{o} a_{o}
$$

where $a_{o}$ is the unit labour coefficient, $w_{o}$ is the equilibrium wage, and $\tau_{o d}$ is the bilateral iceberg cost. Thus, exports from $o$ to $d$ are:

$$
V_{o d}=\tau_{o d} w_{o} a_{o} x_{o d}=\left(\frac{\tau_{o d} w_{o} a_{o}}{P_{d}}\right)^{1-\sigma} E_{d}
$$

Here $V_{o d}$ is the aggregate value of telemigration payments from $o$ to $d$, i.e., the bilateral value of trade in services.

Finally, we use the general equilibrium adding-up condition to solve for prices and wages. Nation $o$ has income $Y_{O}=w_{o} L_{o}$ (where $L_{o}$ is the labour supply), which in general equilibrium, must match output, so wages have to adjust such that $Y_{o}=\sum_{d=1}^{R} V_{o d}$. Thus:

$$
Y_{o}=\left(w_{o} a_{o}\right)^{1-\sigma} \sum_{d=1}^{R}\left(\tau_{o d}{ }^{1-\sigma} \frac{E_{d}}{P_{d}^{1-\sigma}}\right)
$$

Solving for the producer price of the services in nation $o$, we get:

$$
p_{o}{ }^{1-\sigma}=\frac{Y_{o}}{\Omega_{o}}, \quad \text { where } \quad \Omega_{o} \equiv \sum_{i=1}^{R}\left(\tau_{o i}{ }^{1-\sigma} \frac{E_{i}}{P_{i}{ }^{1-\sigma}}\right)
$$

Here $\Omega_{o}$ is a measure of market access; the capital-omega is a mnemonic for 'openness' since it measures the openness of nation $o$ 's exports to world markets.

Plugging in the solution into the expression for $V_{o d}$ is the last step. It yields a first-pass gravity equation for offshoring:

$$
V_{o d}=\tau_{o d}^{1-\sigma}\left(\frac{Y_{o} E_{d}}{\Omega_{o} P_{d}^{1-\sigma}}\right)
$$

Thus, $Y_{o}$ is the total labour income of teleworkers in origin nation $o$, and $E_{d}$ is the spending in destination nation $d$ on labour in teleworkable jobs. This could be estimated in log-linear form.

The two core messages from Sections 2 and 3 are that 1) offshoring jobs will generate cross-border trade in services, and 2) bilateral trade in services can be empirically modelled using the gravity equation. To illustrate how one may use the gravity-based approach to quantify potential trade in services, we update gravity regressions estimated by Head, Mayer, and Ries (2009). Using Eurostat data covering 1992-2006, they found a strong negative correlation between physical distance and bilateral trade in services.

\section{Quantifying potential growth in trade in services}

The combined forces of rapid technological progress in digital communication tools (Baldwin 2019) and an extended experiment with remote work imposed by the coronavirus pandemic (Dingel and 
Neiman 2021) may substantially reduce the importance of physical proximity for trade in services relative to the turn of the century. We use the gravity regression to illustrate the scope for greater services trade if physical distance becomes less relevant and discuss the frictions associated with cultural, linguistic, and social differences between trading nations.

Unfortunately, data on trade in services is quite crude relative to data on trade in goods - and extremely crude compared to the occupation-level data used in Blinder (2007) and Dingel and Neiman (2020) and shown in Figures 2.2 through 2.4. There are more than 800 distinct 6-digit occupations in those data sets. The ILO provides employment counts for 40 distinct 2-digit occupational groups for more than 80 countries. By contrast, bilateral trade flows for services are reported for only a dozen or so broad categories of services. Head, Mayer, and Ries (2009) report estimates for only four categories of services trade.

The advantage of using reported flows of services trade is that it allows one to assess the role of international business frictions without having to construct a model of the relevant economic masses. As mentioned, these masses are absorbed in importer-year and exporter-year fixed effects. The consequences of differences in language, cultural and physical proximity are estimated using variation in services trade across pairs of countries.

\subsection{Data}

We estimate gravity service regressions using data released since Head, Mayer, and Ries (2009) henceforth HMR - wrote their study. We use trade flows for 12 service sectors in 2005-2019, as reported by the OECD-WTO Balanced Trade in Services (BaTIS) dataset, and flows for 11 service sectors in 1995-2006, as reported in the previous BaTIS edition (Fortanier et al. 2017; Liberatore and Wettstein 2021). In sharp contrast to the data employed by HMR, these services trade data sets report very few zeros. ${ }^{6}$ Following HMR, we include log physical distance, differences in time zones, and dummy variables indicating a colonial relationship, shared language, and a common legal system for each pair of countries. ${ }^{7}$

While one might combine estimates of the frictions impeding international services trade with proxies for latent occupation-level demand and supply for teleworkable tasks, here we confine ourselves to discussing the direct effects associated with the estimated elasticities of the gravity regression.

\subsection{Gravity estimates of bilateral frictions for trade in services}

Table 4.1 shows our results for total services. The first 5 columns are for the 1995-2006 period (corresponding to the original HMR period). The signs and magnitudes of the point estimates are all reasonable in light of their prior findings. Like HMR, we find that distance has a large, negative coefficient that is more negative than what is typically found for goods trade. Given that the totalservices data are such a grab-bag of phenomena - everything from airline tickets and online game playing to pipeline fees and call centres - it is hard to characterize all the roles bilateral distance may play. It may seem counterintuitive that distance should matter more for trade in services, which is less connected to the transportation of physical objects. Total services, however, includes many flows for which face-to-face interaction may be important for setting up, maintaining, or operating the international exchange. For instance, distribution services, tourism, transportation, and financial services are all major services categories and likely require managers and specialists to move among

\footnotetext{
' See Liberatore and Wettstein (2021) for a detailed description of the relevant data construction and imputation procedures underlying the BaTIS data.

We obtain the distance, colonial, and language covariates from the CEPII website associated with Head, Mayer, and Ries (2010) and Head and Mayer (2014). We obtain the legal-origin covariate from La Porta, Lopez-de-Silanes, and Shleifer (2008). We use time-zone data posted by Herman Wong.
} 
facilities. The coefficients on time-zone differences, shared language, colonial link, and shared legal origin are all significant in the full sample.

Table 4.1 Total-services gravity regressions: various country samples, linear fixedeffects model

\begin{tabular}{lcccccc}
\hline & & & & & & $2005-2019$ \\
& $(1)$ & $(2)$ & $(3)$ & $(4)$ & $(5)$ & $(6)$ \\
& Full & EU & OECD & G20 & EU/OECD & EU/OECD \\
\hline Distance (log) & $-1.155^{a}$ & $-1.763^{a}$ & $-1.505^{a}$ & $-0.746^{a}$ & $-1.475^{a}$ & $-1.249^{a}$ \\
& $(0.007)$ & $(0.046)$ & $(0.034)$ & $(0.034)$ & $(0.033)$ & $(0.025)$ \\
Distance (log) $\times$ trend & $-0.009^{a}$ & $0.027^{a}$ & $0.009^{b}$ & -0.004 & $0.009^{b}$ & 0.003 \\
& $(0.001)$ & $(0.006)$ & $(0.004)$ & $(0.005)$ & $(0.004)$ & $(0.002)$ \\
Time zone diff. & $0.080^{a}$ & $-0.310^{a}$ & $0.105^{a}$ & $-0.026^{a}$ & $0.091^{a}$ & $0.057^{a}$ \\
& $(0.001)$ & $(0.030)$ & $(0.006)$ & $(0.004)$ & $(0.006)$ & $(0.004)$ \\
Shared language & $0.473^{a}$ & $-0.331^{a}$ & 0.037 & $0.372^{a}$ & $0.089^{a}$ & $0.205^{a}$ \\
& $(0.007)$ & $(0.058)$ & $(0.030)$ & $(0.036)$ & $(0.028)$ & $(0.022)$ \\
Colonial link & $1.198^{a}$ & $0.104^{c}$ & $0.192^{a}$ & $0.254^{a}$ & $0.273^{a}$ & $0.344^{a}$ \\
& $(0.020)$ & $(0.054)$ & $(0.043)$ & $(0.045)$ & $(0.040)$ & $(0.032)$ \\
Shared legal origin & $0.106^{a}$ & $0.360^{a}$ & $0.272^{a}$ & $0.095^{a}$ & $0.228^{a}$ & $0.180^{a}$ \\
& $(0.004)$ & $(0.022)$ & $(0.015)$ & $(0.023)$ & $(0.015)$ & $(0.011)$ \\
\hline Sample & All & $\mathrm{o}, \mathrm{d}$ in EU & o,d in OECD & o,d in G20 & o,d in EU/OECD & o,d in EU/OECD \\
Obs. & 382,552 & 7,792 & 13,456 & 4,104 & 15,976 & 23,510 \\
$R^{2}$ & 0.845 & 0.925 & 0.926 & 0.914 & 0.917 & 0.914 \\
\hline
\end{tabular}

Notes: Regressions include origin-year and destination-year fixed effects. Statistical significance at the 1\%, $5 \%$, and $10 \%$ levels is indicated by $\mathrm{a}, \mathrm{b}$ and $\mathrm{c}$.

The coefficients vary substantially across estimation samples defined by different sets of countries. This could reflect substantial heterogeneity within the "total services" set of activities. Trade in services within the EU, for instance, likely has a very different composition than trade among the G20 nations. ${ }^{8}$ Beyond such compositional effects, measurement error and other data features may also vary across the samples. Finally, the relevant elasticities may not be global constants. ${ }^{9}$

The sixth column of Table 4.1 reports estimates for more recent years (2005-2019) for the set of nations where both are in the EU and/or the OECD. The estimated effects of distance, shared legal origin, and time-zone are smaller, and the distance trend becomes insignificant, but the effect of shared language more than doubles. The coefficient on the dummy for a colonial link also increases in magnitude. We refrain from overinterpreting these differences in coefficients, since the nature of trade in services shifted considerably between 2005 and 2019, let alone between the 1990s and the later period.

To address some of the concerns about heterogeneity within total services, we present the same regressions for different types of services in Table 4.2. The sample of nations is the EU/OECD sample and the 2005-2019 period, so the first column of Table 4.2 is identical to the sixth column of Table 4.1.

s The G20 countries include members of the European Union, the G7 (France, Germany, Italy, Britain, US, Canada, and Japan), and the BRICS (Brazil, Russia, India, China, and South Africa), plus Argentina, Australia, Indonesia, South Korea, Mexico, Saudi Arabia, and Turkey.

' Indeed, the notably smaller distance elasticity for the G20 sample is driven by observations in the left tail of the bilateral-distance distribution, suggesting a rejection of the constant-elasticity specification. 
Table 4.2 Sectoral gravity regressions: linear fixed-effects model, EU/OECD sample, 2005-2019.

\begin{tabular}{|c|c|c|c|c|c|}
\hline & $\begin{array}{c}(1) \\
\text { Total }\end{array}$ & $\begin{array}{c}(2) \\
\text { OCS }\end{array}$ & $\begin{array}{c}(3) \\
\text { Finance }\end{array}$ & $\begin{array}{l}(4) \\
\text { IT }\end{array}$ & $\begin{array}{c}(5) \\
\text { OBS }\end{array}$ \\
\hline Distance (log) & $\begin{array}{c}-1.249^{a} \\
(0.025)\end{array}$ & $\begin{array}{c}-1.285^{a} \\
(0.030)\end{array}$ & $\begin{array}{l}-1.517^{a} \\
(0.039)\end{array}$ & $\begin{array}{c}-1.253^{a} \\
(0.035)\end{array}$ & $\begin{array}{c}-1.219^{a} \\
(0.033)\end{array}$ \\
\hline Distance $(\log ) \times$ trend & $\begin{array}{c}0.003 \\
(0.002)\end{array}$ & $\begin{array}{c}0.006^{b} \\
(0.003)\end{array}$ & $\begin{array}{c}-0.001 \\
(0.004)\end{array}$ & $\begin{array}{c}0.012^{a} \\
(0.004)\end{array}$ & $\begin{array}{c}-0.002 \\
(0.003)\end{array}$ \\
\hline Shared language & $\begin{array}{c}0.205^{a} \\
(0.022)\end{array}$ & $\begin{array}{c}0.188^{a} \\
(0.025)\end{array}$ & $\begin{array}{c}0.226^{a} \\
(0.039)\end{array}$ & $\begin{array}{c}-0.000 \\
(0.032)\end{array}$ & $\begin{array}{c}0.197^{a} \\
(0.030)\end{array}$ \\
\hline Colonial link & $\begin{array}{c}0.344^{a} \\
(0.032)\end{array}$ & $\begin{array}{c}0.234^{a} \\
(0.037)\end{array}$ & $\begin{array}{c}0.220^{a} \\
(0.051)\end{array}$ & $\begin{array}{l}0.295^{a} \\
(0.045)\end{array}$ & $\begin{array}{c}0.163^{a} \\
(0.042)\end{array}$ \\
\hline
\end{tabular}

NOTES: Regressions include origin-year and destination-year fixed effects. Statistical significance at the 1\%, $5 \%$, and $10 \%$ levels is indicated by a, b and c. The service sectors are Other Commercial Services ("OCS", which is non-government services that are not transportation or travel), Finance (financial services including those delivered locally by foreign branches, etc), IT (includes telecommunications and software services), and Other Business Services ("OBS", which is trade related services, operational leasing/rentals, and miscellaneous business, professional and technical services such as legal, accounting, management consulting, public relations services, advertising, market research and public opinion polling, research and development services, architectural, engineering, and other technical services, agricultural, mining and on-site processing).

The results show that there is meaningful variation in the point estimates across service categories, but most of them retain the expected sign and not too dissimilar magnitudes. Contrasting Tables 4.1 and 4.2 shows that the sample of countries used has a much greater influence on the estimated coefficients than breaking out total services trade into component categories.

When thinking about telemigration, the category that corresponds most clearly to the model we have in mind is 'Other Business Services' (OBS) shown in column 5. Since the EU/OECD sample does not include India - a key player in telemigration - we present analogous estimates for recent years for a sample of nations that includes all the $\mathrm{G} 20$ nations as origin and destination countries in Table 4.3. 
Table 4.3 Sectoral gravity regressions: linear fixed-effects model, G20 sample, 20052019.

\begin{tabular}{lccccc}
\hline & $(1)$ & $(2)$ & $(3)$ & $(4)$ & $(5)$ \\
& Total & OCS & Finance & IT & OBS \\
\hline Distance (log) & $-0.775^{a}$ & $-0.696^{a}$ & $-0.831^{a}$ & $-0.901^{a}$ & $-0.707^{a}$ \\
& $(0.026)$ & $(0.028)$ & $(0.039)$ & $(0.032)$ & $(0.029)$ \\
Distance (log) $\times$ trend & 0.004 & 0.003 & 0.001 & $0.009^{a}$ & 0.004 \\
& $(0.003)$ & $(0.003)$ & $(0.004)$ & $(0.003)$ & $(0.003)$ \\
Time zone diff. & $-0.011^{a}$ & $-0.014^{a}$ & 0.007 & -0.003 & -0.001 \\
& $(0.003)$ & $(0.003)$ & $(0.005)$ & $(0.004)$ & $(0.003)$ \\
Shared language & $0.431^{a}$ & $0.477^{a}$ & $0.558^{a}$ & $0.384^{a}$ & $0.396^{a}$ \\
& $(0.024)$ & $(0.027)$ & $(0.039)$ & $(0.035)$ & $(0.029)$ \\
Colonial link & $0.185^{a}$ & 0.054 & $-0.150^{b}$ & $0.087^{b}$ & -0.036 \\
& $(0.034)$ & $(0.042)$ & $(0.059)$ & $(0.042)$ & $(0.035)$ \\
Shared legal origin & $0.067^{a}$ & $0.074^{a}$ & $-0.046^{b}$ & $0.126^{a}$ & $0.173^{a}$ \\
& $(0.015)$ & $(0.020)$ & $(0.023)$ & $(0.021)$ & $(0.021)$ \\
\hline Sample & $\mathrm{o}, \mathrm{d} \mathrm{in} \mathrm{G20}$ & o,d in G20 & o,d in G20 & o,d in G20 & o,d in G20 \\
Obs. & 5,130 & 5,130 & 5,119 & 5,130 & 5,129 \\
$R^{2}$ & 0.926 & 0.925 & 0.913 & 0.910 & 0.921 \\
\hline
\end{tabular}

Notes: Regressions include origin-year and destination-year fixed effects. Statistical significance at the 1\%, $5 \%$, and $10 \%$ levels is indicated by a, b and c. For service sector definitions, see notes of previous table.

The point estimates for the OBS column of Table 4.3 are the ones we use in the quantification exercise. The next step is to think about how to relate the flow of services to jobs.

\subsection{Translating services flows into jobs}

Embracing the bold approximation that OBS services imports are payments to foreign service workers, the bilateral service trade flow can be interpreted as the "wage bill" for telemigrants between pairs of countries. This is crude, but it allows us to tackle order-of-magnitude questions when it comes to the impact of making telemigration easier.

Put simply, emerging economies currently export very modest volumes of other business services. In 2019 , China and India's total OBS exports were $\$ 68$ billion and $\$ 51$ billion, respectively. These small initial volumes would need to expand massively to be associated with meaningful numbers of new telemigrant jobs. If telemigrants earned $\$ 10,000$ per year ( $\$ 5$ an hour for 2000 hours per year), a doubling of OBS exports would only create a few million telemigrants in these economies.

Consider how many jobs might come from increased bilateral exports to the US or EU as a result of lower service trade costs. Since physical distance is the canonical shifter of bilateral trade costs, we consider the consequences of reducing its negative impact on bilateral services trade. Per Table 4.3, the estimated impact of distance on trade became less negative during 2005-2019. However, this trend is neither statistically nor economically significant. The estimated coefficient on the interaction of log distance and a linear time trend $(0.004)$ is less than $1 \%$ of the log-distance coefficient $(-0.707)$. At that rate, decades would have to pass for an appreciable change in trade volumes to arise. Rather than tracing out the impact of this trend, we choose to consider the consequences of a more radical shift.

Our thought experiment is to consider the numbers of emerging-market jobs that might be created by a $25 \%$ decline in the bilateral distance between economies. Imagine the reduced cost of physical 
distance applying to one pair of countries in isolation. For example, it is about 14,000 kilometres from Palo Alto to Bangalore; slicing off a quarter of this distance would put Bangalore near Taipei. The distance elasticity of -0.707 implies export would be about $18 \%$ higher. We then translate this change in export value into a number of telemigrants by our crude assumption about wages. This calculation overstates the increase in bilateral exports and the number of telemigrants to the extent that it neglects substitution between export destinations and general-equilibrium effects on wages that would dampen the response.

The first line of Table 4.4 reports the value of US OBS imports in 2019 from four partners: China, India, Brazil, and Canada. The United States is the largest destination for Brazilian, Canadian, and Indian exports of OBS. It is China's second largest destination after Hong Kong. The figures are all very modest: about $\$ 11$ billion from India and Canada and even less from China and Brazil. Thus, any export growth will be starting from low initial values. Consolidated across all EU members, China and India do export more OBS to the EU, but these values are again modest. These small flows explain why even seemingly large changes in the impact of distance on OBS flows will have rather modest effects on jobs.

We convert the import values to a baseline of foreign jobs using a proxy for the relevant foreign wage: the average hourly wage of an IT worker. US workers in computer and mathematical occupations average $\$ 41.51$ per hour (Dingel and Neiman 2020). Canadian wages are about threequarters of that, while those in Brazil, China and India are notably lower. ${ }^{10}$ The resulting numbers of telemigrant jobs suggested by the calculation are 190,000 in Canada, 400,000 in Brazil, 360,000 in China, and 2.38 million in India.

As a result, the jobs increases associated with an $18 \%$ increase in US OBS imports are very modest. For India, the number is 420,000 more telemigrant jobs. The figure is less than 70,000 for the three other economies. The job increases associated with increased exports to the EU are similarly modest.

\footnotetext{
${ }^{10}$ Hourly wages for "natural and applied sciences and related occupations" in Canada are 37.87 CAD (StatCan Table 14-10-0340-01 for 2019 full-time employees). Average monthly earnings for information, communication, financial, and professional occupations in Brazil were 3,445 BRL in 2019 (Q27 in Pesquisa Nacional Por Amostra De Domicílios contínua, Instituto Brasileiro de Geografia e Estatística, 2012-2020). Urban male "technicians \& associate professionals" in India average 28,923 INR per month (Table 55, Annual Report, Periodic Labour Force Survey, 2019-20). Average earnings for "information transmission, software, and information technology" workers in China were 161,352 CNY per year in 2019 (Table 4-15, China Statistical Yearbook 2020). We convert these to US dollars at (roughly) $1 \mathrm{CAD}=0.79 \mathrm{USD}, 1 \mathrm{BRL}=0.19 \mathrm{USD}, 1 \mathrm{CNY}=$ 0.15 USD, and 1 INR $=0.013$ USD. We assume 2,000 hours of work per year.
} 
Table 4.4: Increases in telemigration associated with $25 \%$ reduction in bilateral distance

\begin{tabular}{lrrrr}
\hline & Canada & Brazil & China & India \\
\hline Telemigrants selling to US & & & & \\
US OBS imports in 2019 (billions USD) & 11.37 & 3.19 & 8.85 & 11.13 \\
Hourly wage & 30.00 & 3.96 & 12.45 & 2.34 \\
Base jobs (millions) & 0.19 & 0.40 & 0.36 & 2.38 \\
Percent increase in US imports of OBS & 0.18 & 0.18 & 0.18 & 0.18 \\
Jobs increase (millions) & 0.03 & 0.07 & 0.06 & 0.42 \\
\hline Telemigrants selling to EU & & & \\
EU OBS imports in 2019 (billions USD) & 5.52 & 4.18 & 22.31 & 18.32 \\
Hourly wage & 30.00 & 3.96 & 12.45 & 2.34 \\
Base jobs (millions) & 0.09 & 0.53 & 0.90 & 3.91 \\
Percent increase in EU imports of OBS & 0.18 & 0.18 & 0.18 & 0.18 \\
Jobs increase (millions) & 0.02 & 0.09 & 0.16 & 0.69 \\
\hline NotES: This table computes the jobs increases associated with the bilateral export in- \\
creases implied by bilateral distance declining by 25\%. OBS imports in 2019 are from \\
WTO data. Hourly wages for IT workers are from payscale.com. The distance elasticity \\
is from Table 4.3 column 5. We assume 2,000 hours of work per year. Remaining numbers \\
are authors' calculations.
\end{tabular}

The headline result from these calculations is that the job-impact numbers are very small when we compute growth from initially small bilateral export values. India's labour force is in the region of a half-billion workers. The job impact suggested by the rough calculations in Table 4.4 is tiny compared to that. The job increases for Brazil and China are similarly modest.

Of course, physical distance is not the only source of trade costs. New digital tools and organizational practices might diminish the frictions associated with time-zone or linguistic differences. One could compute such consequences similar to our distance-driven scenario above. But an important reason the jobs numbers in Table 4.4 are small is that the 2019 exports of other business services are small, implying a small number of new telemigrants associated with any modest shift in trade costs.

\subsection{Modest changes are insufficient for a big development impact}

Our rough quantification exercise could be greatly refined, but refinements of the elasticities estimated in Section 4.2 are essentially immaterial to the basic conclusion. The current volume of service trade of the type that could be construed as representing payments to telemigrants is just too small for a doubling or tripling to have meaningful consequences for emerging markets' development trajectories. A radical increase in trade flows would be necessary to produce many new service-sector jobs in emerging markets. This is not impossible. ${ }^{11}$ For example, between 2005 and 2019, the nominal value of Other Business Services exported by China and India both had annual growth rates of $12 \%$. Such growth also reflects supply shifts, not merely declining trade costs.

The next section explores the economic logic of a model in which modest changes in the frictional barriers to trade in services could lead to more radical changes than those suggested by our quantification exercise.

\footnotetext{
"Indeed, Kehoe and Ruhl (2013) emphasize the contribution of growth in previously least-traded goods to total trade growth in episodes of structural transformation and trade liberalization.
} 


\section{A simple model of telemigration: Could comparative advantage work differently with services?}

Telemigration evokes anxiety in rich nations. "This year's mass experiment with remote working has, for some, triggered a prickling sense of unease: if I can do my job from home in London, Brooklyn or Canberra, could someone else do it more cheaply from Sofia, Mumbai or Manila?" wrote Sarah O'Connor (2020) in the Financial Times. The fear is that digitally enabled telemigration will be asymmetric: It will expose tens of millions of office workers based in rich nations to foreign competition without providing them additional, offsetting export opportunities.

Is this anxiety well-founded? The conventional gravity approach would suggest that it is not. In these quantitative models, the elasticity of trade flows with respect to trade costs is constant. As a result, the direct effect of a common decline in the costs of trading services is a common proportionate increase in the exports of services by all economies. Even neglecting developed economies' potential export expansion, the quantification of their increased imports from emerging economies suggests that the number of jobs at stake is modest. There is some nuance in terms of general-equilibrium effects, but the assumptions of the gravity equation that make the pattern of comparative advantage symmetric and the trade elasticity constant essentially rule out highly asymmetric responses to a common decline in trade costs. On the other hand, we have little evidence to support restricting attention to these particular functional forms.

Two intriguing empirical patterns suggest that it may be fruitful to build a model that allows us to illustrate the possibility behind the anxiety. First, most rich nations run a trade surplus in services and so would seem to have a comparative advantage in services (WTO 2019, Figure B.9). Specifically, developed nations account for about $75 \%$ of global service exports, and they export more than they import. Most of this services trade, about $70 \%$, takes place in so-called traditional services. Specifically, these are distribution services (20\% of world total), financial services (19\%), telecommunications, computer and audio-visual services (13.2\%), transportation (12\%), and tourism $(8 \%) .{ }^{12}$ Correspondingly, developing countries as a whole are net importers of services. In a conventional gravity model, a decline in the cost of trading services would reinforce this initial pattern of comparative advantage.

The second fact is that developing economies have the edge in office and professional services that are exported via digital platforms (ILO 2021). These categories are currently much smaller than traditional services (Other Business Services and professional services account for $4 \%$ and $3 \%$ of world services trade, respectively), but they are growing faster. The fact that rich nations are running trade deficits in one of the fastest-growing service-trade segments raises the possibility that further advances in digital technology may not simply reinforce past patterns of trade in services.

To evaluate the possibility that the future expansion of service trade may be asymmetric, we need a general-equilibrium trade model that allows us to address two key questions. Why are today's services exports largely "running uphill," from high-wage nations to low-wage nations? Why is there a presumption that reducing the costs of telemigration will lead to an asymmetric rise in crossborder flows that reverses this pattern? Along the way, the model will allow us to consider a few other issues such as: "How do low trade costs for goods interact with higher trade costs for services?" and "If international relative wages are mostly determined today by things like international labour productivity differences and country size, what happens to relative wages when telemigration gets much easier?"

To address these questions, we use the Dornbusch, Fischer, and Samuelson (1977) - henceforth DFS - model as a basis for thinking about telemigration. The model is familiar, so we move through the

12 2017 values from Figure B.2 of WTO (2019). 
analysis quickly. To fix ideas and introduction notation, we first present the well-known DFS model for trade in goods.

\subsection{The DFS model for goods}

The world economy has two nations (North and South). Markets are perfectly competitive. There is a continuum of goods, indexed by $z$. Production employs only labour and exhibits constant returns to scale. Labour endowments in North and South are $L$ and $L^{*}$, respectively. Unit costs for good $z$ are:

$$
w a(z), \quad w^{*} a^{*}(z), \quad z=0 \ldots 1
$$

where $a(z)$ and $a^{*}(z)$ are the unit labour input coefficients for North and South, and $w$ and $w^{*}$ are their respective wages. North, as the rich nation, is assumed to have an absolute advantage in every sector, but only relative efficiencies, $a^{*}(z) / a(z)$, matter for the pattern of trade (Ricardo 1817). Indexing the sectors so that North's productivity advantage is greatest in low-z sectors, we have:

$$
A(z)=\frac{a^{*}(z)}{a(z)}>1, \quad A^{\prime}(z)<0, \quad \omega=\frac{w}{w^{*}}, \quad z=0 \ldots 1
$$

North's wage relative to South's wage is $\omega$. Preferences are identical across people and nations and are Cobb-Douglas with $\mathrm{b}(\mathrm{z})$ as the expenditure share for good $\mathrm{z}$. Also, $B\left(z^{\prime}\right)=\int_{0}^{z \prime} b(z) d z$ and $B(1)=1$.

\section{Adding trade costs}

Trade is subject to symmetric, iceberg trade costs, so firms must ship $\tau>1$ units to sell one unit in the other nation; domestic trade is costless. Since North goods pay $\tau$ to get inside South's market, the South-market threshold or borderline good, which we label as $z_{S}$, is defined by the equal price condition $\tau w a\left(z_{S}\right)=w^{*} a^{*}\left(z_{S}\right)$; likewise the North-market threshold good, $z_{N}$, is defined by $w a\left(z_{N}\right)=\tau w^{*} a^{*}\left(z_{N}\right)$.

Closing the model requires the relative wage, and this is determined by the North labour market clearing condition. Given the preferences, it is: $w L=w^{*} L^{*} B\left(z_{S}\right)+w L B\left(z_{N}\right)$ because North consumers buy North-made goods in the $0 . \ldots z_{N}$ range while South consumers spend only on North export goods, $0 \ldots z_{S}$. To recap, the three equilibrium conditions are:

$$
\tau \omega=A\left(z_{S}\right), \quad \omega=\tau A\left(z_{N}\right), \quad \omega=\frac{B\left(z_{N}\right)}{1-B\left(z_{S}\right)} \frac{L^{*}}{L}
$$

It is convenient to have a simple, two-dimensional diagram, so we collapse the 3-equation system into a 2-equation system by assuming explicit functional forms. We assume $A(z)=1 / z$, and $b(z)=1$ for all $z$, so $B\left(z^{\prime}\right)=z^{\prime}$. Additional simplification comes from supposing $\mathrm{L}=\mathrm{L}^{*}$. With these, $z_{N}=z_{S} \tau^{2}$ and the equilibrium conditions are:

$$
\omega=\frac{\tau}{z_{F}}, \quad \omega=\frac{z_{F}}{1-z_{F}} \tau^{2}
$$

The equilibrium $\omega, z_{F}$ are defined by the intersection of the two conditions in the left panel of Figure 5.1 .

The right panel shows the classic non-traded goods analysis in DFS. The upward sloped line is the ratio of North to South production costs; it is linear due to $A(z)=1 / z$.

- When North's relative cost is low enough, it is competitive inside the South market despite the trade cost. This is true for the range zero to $z_{S}$; North exports these goods.

- When North's relative cost is high enough, South goods are competitive in North despite the trade costs. This is true for the range from $z_{N}$ to unity; South exports these goods.

- Goods between the two thresholds are non-traded. 
Note that neither of the two key questions is clarified by this diagram. The trade is not particularly "uphill" (exports and imports necessarily balance in value terms), and a reduction of $\tau$ would bring forth more North and more South exports in the same proportion (an outcome that is indeed guaranteed by the equilibrium conditions).

\section{Figure 5.1: DFS model and non-traded goods}
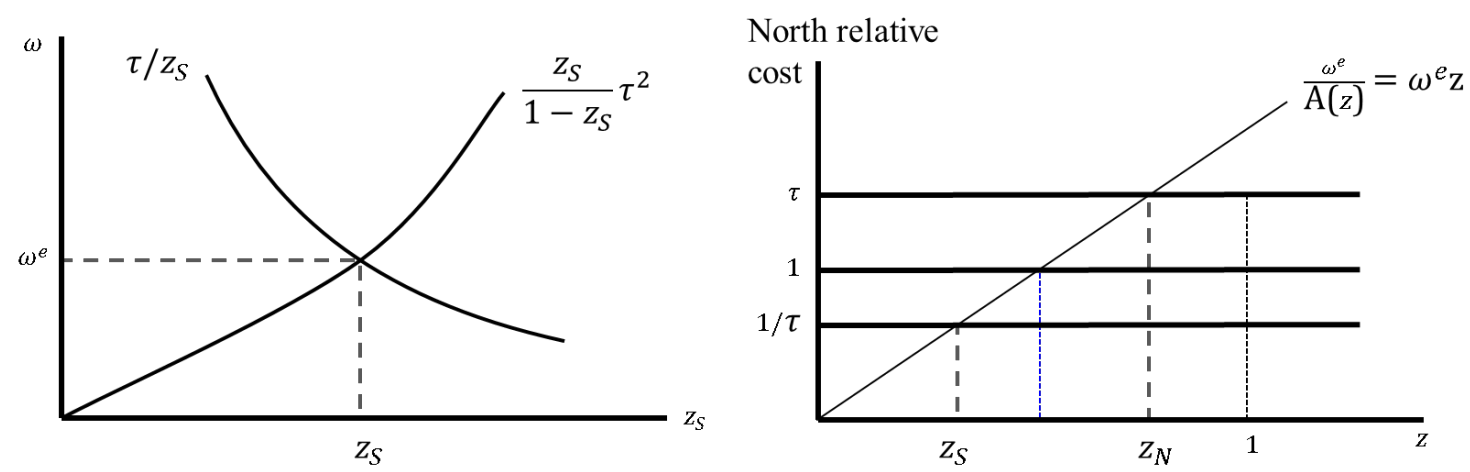

Source: Authors' elaboration.

We laid out this goods-only model to fix ideas and notation. It also gives us a departure point where most trade is in goods, so $\omega$ is predominately determined by goods trade.

\subsection{A simple model of telemigration: Adding services and service-linked trade costs}

Adding services is simple if we embrace a two-tier Cobb-Douglas preferences structure with $\gamma$ as the expenditure share on goods (gamma is a mnemonic for goods). Here we are taking the task approach to services akin to the model of Grossman and Rossi-Hansberg (2006).

We label the relative productivity curve for service 'tasks' as:

$$
S(t)=\frac{s^{*}(t)}{S(t)}>1, \quad S^{\prime}(t)<0, \quad \tau_{S} \omega=S\left(t_{S}\right), \quad \omega=\tau_{S} S\left(t_{N}\right)
$$

where $s(t)$ and $s^{*}(t)$ are the unit labour input coefficients for North and South service "tasks" ( $s$ and $t$ are mnemonics for services and tasks respectively). The final two expressions define the threshold tasks, $t_{N}$ and $t_{S}$, which delineate the non-traded services range. The new labour clearing market condition, which now must include spending on services, is: $w L=\gamma\left\{w^{*} L^{*} z_{S}+w L z_{N}\right\}+$ $(1-\gamma)\left\{w^{*} L^{*} t_{S}+w L t_{N}\right\}$. This simplifies to:

$$
\omega=\frac{\gamma z_{S}+(1-\gamma) t_{S}}{1-\left\{\gamma z_{N}+(1-\gamma) t_{N}\right\}}
$$

\section{Assumptions reflecting the peculiarities of services trade: The "hockey stick"}

We add two elements to the model to adapt it to the services context. First is that the trade costs in services are very high - so high that there is little cross-border trade in services (compared to the size of the sector). This echoes the fact that service provision often requires, or is much easier, when the service provider and buyer are in the same room at the same time (and moving humans is expensive compared to moving goods). Second, we assume that the pattern of comparative advantage explains the fact that much of this "mode- 1 " services trade consists of Northern exports of highly sophisticated services (finance, engineering, communications, etc).

The first feature - high service trade costs - does not require a modification of the model, just the application of a different parameter value. To get the second feature, however, requires more substantial changes. Specifically, we assume the $1 / \mathrm{S}(\mathrm{t})$ curve has the "hockey-stick" shape shown in Figure 5.2. 


\section{Figure 5.2: Non-traded service tasks in the "service-enabled" DFS model.}

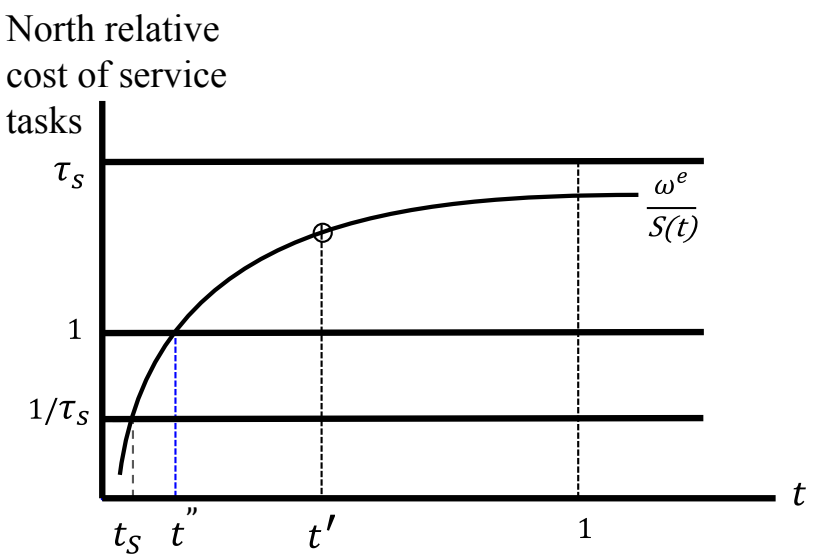

Source: Authors' elaboration.

Before thinking about the microfoundations of the hockey stick shape, consider what the $S(t)$ curve would look like under Eaton and Kortum (2002) assumptions. ${ }^{13}$ When $1 / s(t)$ and $1 / s^{*}(t)$ are Fréchet distributed, as in Eaton and Kortum (2002), the $S(t)$ curve has the shape shown in Figure 5.3. Note that since the support of the Fréchet distribution is unbounded, there will always be extreme values that can overcome any finite level of trade costs. Thus, every country is predicted to exports some tasks, regardless of sectoral-level average productivities. To put it more graphically, the $S(t)$ generated by the Fréchet assumption has two blades: one pointing up and one pointing down. ${ }^{14}$ Moreover, the patterns of manifest comparative advantage (in tasks actually traded) and latent comparative advantage (in non-traded tasks) are the same. That assumption delivers a constant trade elasticity.

By contrast, we consider the single-blade pattern of relative productivities depicted in Figure 5.2. Why might relative productivities exhibit this "hockey-stick" shape? We briefly step outside the model to think about continuous technological diffusion that tends to narrow extreme productivity differences across economies on a task-by-task basis.

Without innovation, there is a natural tendency for the seepage of know-how to flatten the relative productivity curve. Imagine that products and processes are invented in the advanced economy, so $a(z)$ tends to be less than $a^{*}(z)$, but the cross-sectional differences will tend to fade in a Vernon (1966)-like fashion. That is, things such as good roads, institutions, and trust can explain why German workers are more productive than, say, Turkish workers in every sector, but unless German industry keeps innovating, the German-Turkish productivity ratios will tend towards a constant in all sectors. In other words, this mechanism allows for persistent absolute advantages but only shorterlived comparative advantages. The disappearance of comparative advantage is accelerated if the pace of know-how seepage increases with the size of the productivity gap. In this conceptualisation, the $A(z)$ curve gets its slope from the fact that German industry innovates faster in high-technology sectors. The left part of the $A(z)$ curve is continuously pulled upward by fresh innovations even as the gap between $\mathrm{a}(\mathrm{z})$ and $\mathrm{a}^{*}(\mathrm{z})$ is continuously narrowed by technological diffusion. In this story, Germany has a comparative advantage in its most innovative sectors.

\footnotetext{
${ }^{13}$ Eaton and Kortum (2002) note that the Kortum (1997) and Eaton and Kortum (1999) models of innovation and diffusion deliver a Fréchet distribution of productivities. Costinot, Donaldson, and Komunjer (2012) and Caliendo and Parro (2015) provide multi-sector models in which productivities within each sector follow the Fréchet distribution. These models generate constant-elasticity gravity equations for sectoral trade flows. ${ }^{14}$ When $\frac{1}{s(t)}$ and $\frac{1}{s^{*}(t)}$ are Fréchet distributed with the same shape parameter, then the log difference in unit costs, $\ln (S(t))$, follows the logistic distribution.
} 


\section{Figure 5.3: The relative efficiency curve with Eaton-Kortum assumptions}

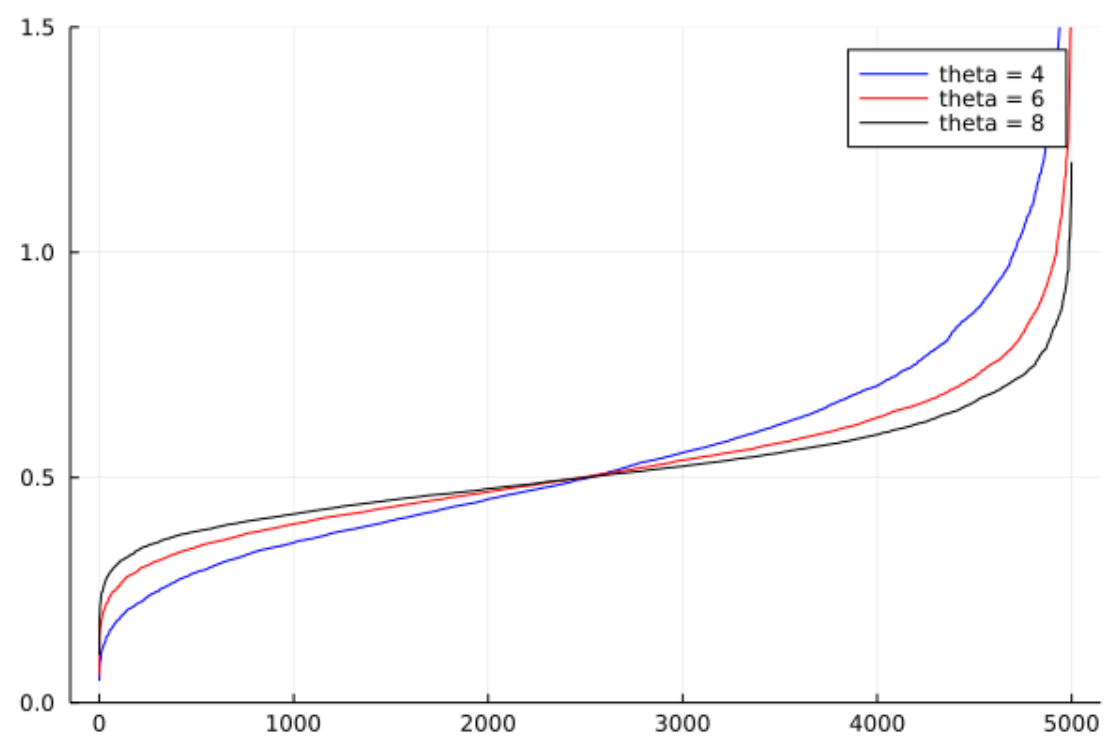

Source: Authors' elaboration; the Fréchet distributions are $F(s)=e^{-2 s^{-\theta}}, F\left(s^{*}\right)=e^{-s^{*-\theta}} \quad s, s^{*} \geq 0$. We randomly sample 5,000 draws from these Fréchet distributions, compute the unit-cost ratios, and plot those ratios in rank order.

\section{Why might $\mathrm{S}(\mathrm{t})$ look like a hockey stick in services but not goods?}

Moving this line of thinking to the service sector, things change since innovation in the service sector is famously slow. This leads to what is known as Baumol's cost disease. A recent University of Chicago Booth School of Business survey of leading economists framed it as: "Because labour markets across different sectors are connected, rising productivity in manufacturing leads the cost of labour-intensive services to rise." Nordhaus (2008) documents the fact.

The point is that slow innovation results in a very flat relative productivity curve as the slow innovation gives technological diffusion enough time to reduce differences in the cross-sector profile of relative labour productivities (i.e., to flatten the S-curve). The exceptions to this are those service tasks that are high-tech. They involve rapid innovation and coordination of many complex things. This is what turns what otherwise would be a "baseball-bat" shaped $1 / \mathrm{S}(\mathrm{t})$ curve into a "hockeystick" shaped $1 / \mathrm{S}(\mathrm{t})$ curve. In particular, it adds the "blade" that indicates that the North has a marked comparative advantage in sophisticated services where innovation is rapid.

\section{Implications of the hockey-stick productivity profile}

It would take substantial empirical investigation to verify that the relative productivity profile has a "hockey-stick" shape. Before economists invest in such research, however, it is useful to show that if it were true, then it would imply intriguing possibilities relative to the standard logistic-shaped curve that is assumed in the conventional gravity model analysis. To that end, we resume the analysis taking the hockey-stick shape as given.

The equal price conditions that define the threshold tasks, $t_{N}$ and $t_{S}$, are $\tau w s\left(t_{S}\right)=w^{*} s^{*}\left(t_{S}\right)$ and $w s\left(t_{N}\right)=\tau w^{*} s^{*}\left(t_{N}\right)$, which imply:

$$
\tau_{S} \omega=S\left(t_{S}\right), \quad \omega=\tau_{S} S\left(t_{N}\right)
$$

As drawn in Figure 5.2, the North's productivity edge is only high enough to overcome the services barriers for a small range of services tasks. Thus, North exports services tasks indexed by zero to $t_{S}$. The inverse $\mathrm{S}(\mathrm{t})$ curve, however, flattens out, so the lower South wage (which is largely determined 
by goods market conditions) is not low enough to allow South service providers to be competitive inside the North market. In other words, South exports no services to the North because $\omega>$ $\tau_{S} S(1)$ : there are no services tasks where the South's relatively low wage is low enough to overcome its productivity disadvantage given the high trade costs. Thus, South exports some goods, and it imports goods and services from North.

The goods sector is crucial to this story. Obtaining the asymmetric trade in services result requires a goods sector where trade is fairly free and comparative advantage is fairly symmetric. Without this, the usual "Ricardian wage equilibration" would drive the relative wage to a point where both North and South were competitive in some service tasks.

The final change is to adapt the equilibrium labour-market condition to incorporate services. For the general case, where both North and South export some service tasks, we will have two service thresholds. In the Figure 5.2 case, however, there is only one, so: $w L=\gamma\left\{w^{*} L^{*} z_{S}+w L z_{N}\right\}+$ $(1-\gamma)\left\{w^{*} L^{*} t_{S}+w L\right\}$, which simplifies to:

$$
\omega=\frac{\gamma z_{S}+(1-\gamma) t_{S}}{\gamma\left(1-z_{N}\right)}
$$

When $t_{S}$ is small, the second expression shows that the relative wage is mostly determined by trade in goods as in the classic DFS model.

\subsection{Telemigration and development}

Here we use the model to guide thinking about how telemigration could affect the future of globalisation. In the initial situation, South service tasks are not competitive inside North, but there is an incipient arbitrage opportunity. If a North firm could - via some new digital technology purchase tasks in South without incurring the trade costs, they would do so for most tasks. For example, if something held the relative wage fixed, but the $\tau_{S}$ became unity for a particular serviceproducing firm in the North, that firm would find it cheaper to source all tasks from $t^{\prime \prime}$ to 1 in the South (see Figure 5.2). This could be the source of the anxiety that is often associated with telemigration. Based on partial-equilibrium thinking, which takes relative wages as fixed, digital technology that makes telemigration easier would seem to bring many more service-sector workers in high-wage nations into direct wage competition with low-wage service workers.

\section{Trade consequence of lower service trade costs}

Figure 5.4 shows what a substantial reduction in the service trade costs would do to the services trade pattern. The blue dashed lines show the new situation with $\tau_{s}$ falling to $\tau_{s}{ }^{\prime}$. This would greatly expand South service exports and only slightly increase North service exports, so the relative demand for North labour would fall - bringing the equilibrium relative wage down from $\omega^{e}$ to $\omega^{e \prime}$.

A twist on this thought experiment that may have some additional contact points with reality considers asymmetric changes in telemigration frictions.

Consider the impact of an asymmetric adoption of the necessary digital technology by North firms but not South firms. For example, we might imagine that the general economic and digital conditions in the North make it easy for South workers to telemigrate Northwards, but the "digital divide" makes it hard for North workers to telemigrate Southwards. In this case, it becomes much easier for South to exports services since, for instance, the North digital coverage and sophistication makes it easier for North firms to integrate remote workers in their service value chains.

The main message from this model is that digital technology could open much greater export opportunities for South-based telemigrants than North-based telemigrants. In other words, the anxiety in the popular debate can be rationalised by a profile of comparative advantage in services of the hockey-stick shape. 


\section{Figure 5.4: Asymmetric expansion of service exports}

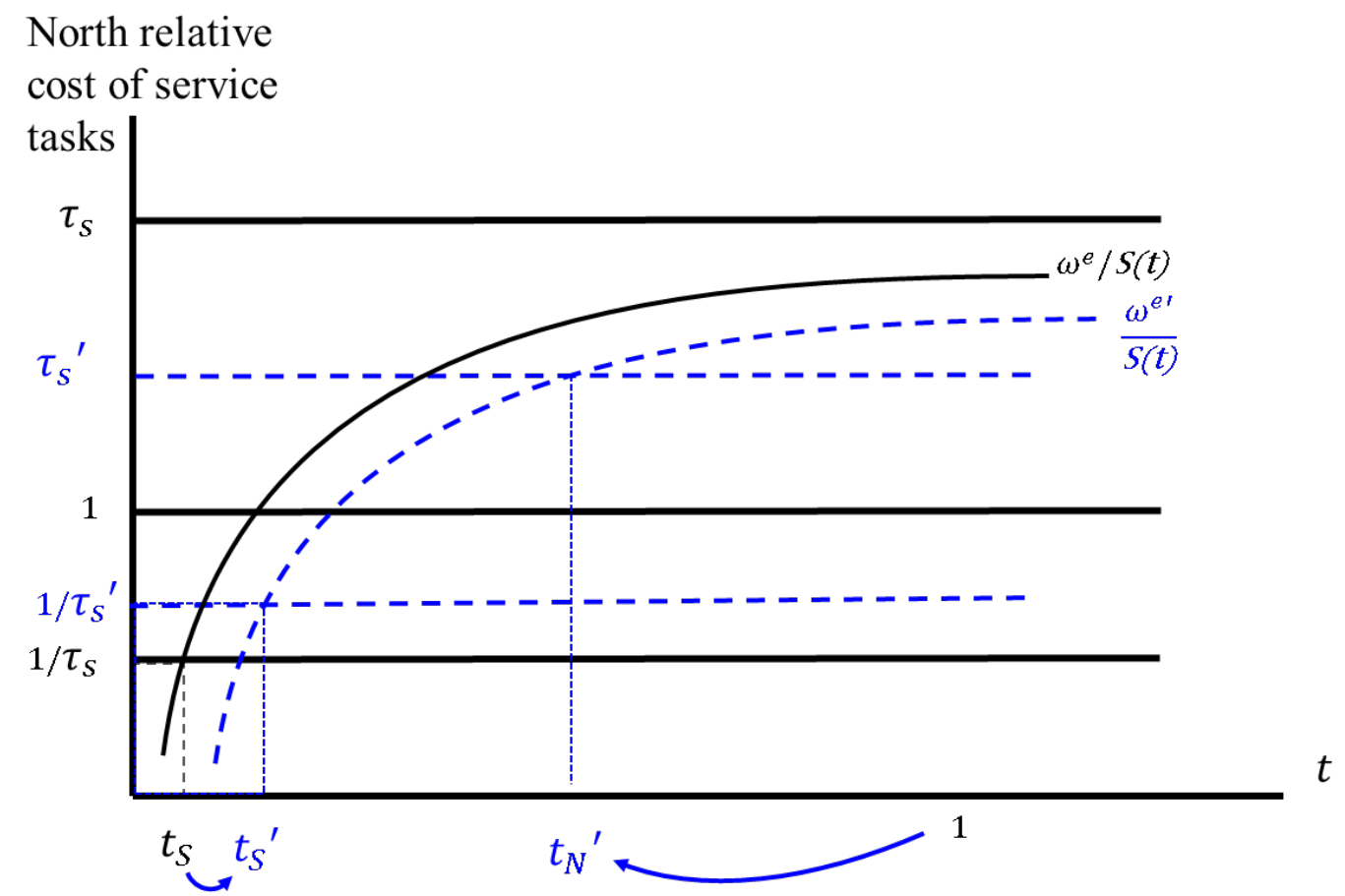

Source: Authors' elaboration.

Given this pattern of productivities, for many office workers and professionals in high-wage nations, telemigration would be a new source of competition, while it would be a new source of opportunities for rather fewer high-wage workers. With the "twin-blades" model of Figure 5.3, rapid technological advances that made remote workers less remote create vast new export opportunities. In other words, if the pandemic-induced experience of "work from home" portends a shift to "work from anywhere" but substantially increased trade in services mimics the current pattern of trade in services, then developed economies will experience substantial services export growth.

For completeness, we solve for the equilibrium when there is costless trade in both goods and services. ${ }^{15}$

\section{Concluding remarks}

The Covid-19 pandemic has introduced huge numbers of employers and employees to remote work. Remote-work arrangements that had been technologically feasible for years but not broadly employed were rapidly adopted in the absence of any alternative. As the economy returns to normal, employers are likely to re-evaluate the kinds and numbers of workers that they employ.

\footnotetext{
${ }^{15}$ With free trade, there is only one threshold in goods and one in services, which we label as $z^{e}$ and $t^{e}$. The equilibrium conditions are: $\omega^{e}=A\left(z^{e}\right), \omega^{e}=S\left(t^{e}\right), \omega^{e}=\frac{\gamma z^{e}+(1-\gamma) t^{e}}{1-\left\{\gamma z^{e}+(1-\gamma) t^{e}\right\}}$. To provide closed-form solutions we can assume that the $S(t)$ curve takes the form $S(t)=1 / \sqrt{t}$. This does not fully reflect the hockey stick shape, but it makes calculations simple and thus transparent. Imposing functional forms: $\omega^{e}=\frac{1}{z^{e}}, \omega^{e}=\frac{1}{\left(t^{e}\right)^{1 / 2}}, \gamma=\frac{1}{2}$.
} 
Some may return to their pre-pandemic practices, but massive disruptions produce opportunities to pivot, and some temporary shocks have permanent consequences. Some investments in remote work capacity are very likely to stick (Barrero, Bloom, and Davis 2021).

It seems inevitable that some of the tasks that can be done remotely will be done by telemigrants rather than domestic workers. Again, this will not be due to a massive change in the frontier of possibilities - telemigration is already widespread in sectors like web design and customized software development. It will, if it happens, be due to many more firms changing practices to adopt these technologies. In short, it would seem that the pandemic has brought forward the date of the "Next Industrial Revolution" that Alan Blinder (2006) famously contemplated a decade and a half ago.

This paper is an attempt to think about how we might evaluate the size of the increased offshoring of office and professional jobs from high-wage to low-wage nations. The starting point is to recognize that many jobs that can be performed remotely require soft skills that make domestic and foreign workers imperfect substitutes. The equilibrium number of telemigrants, therefore, depends on the number of potential foreign suppliers of these tasks and the bilateral frictions that impede trade in these services.

Our quantification is based on two simple ingredients. The first is interpreting trade in certain services as payments to telemigrants so that the gravity equation for trade flows can be used to describe how the volume of transactions will respond to lower trade costs. We updated gravity regressions estimated by Head, Mayer, and Ries (2009) to ballpark these magnitudes. The second ingredient is to assess the development potential of this trade by crudely translating trade flows into numbers of jobs using average wages and the approximation that payments for these services are mainly payments to workers. This is clearly not true for some types of services trade - fees for using oil pipelines, for instance - but it seems sensible for categories like Other Business Services, which contains many of the activities that would be transformed by remote work going global.

Our quantification exercise yields a simple message: the number of offshored jobs is unlikely to be transformative when it comes to the development paths of most emerging economies. This conclusion stems from a point of fact and a point of economic logic. First, the current baseline of trade in Other Business Services is very small. Multiplying these flows by a factor of two or three would not translate to many jobs in emerging markets. Second, quantitative trade models that assume constant elasticities cannot generate very large responses to modest declines in trade costs. There are no "tipping points" in canonical structural gravity models.

The final contribution of our paper is to propose a simple model of telemigration in which modest changes in trade costs can have large effects. The key ingredient is that the pattern of comparative advantage has a hockey-stick shape rather than the symmetric shape typically assumed in quantitative trade models. In this account, emerging markets have tremendous potential to export services that is not evident in the current pattern of trade flows.

Our paper raises many questions for future research. It suggests that making the optimistic case for telemigration-led development will be harder than one might have thought. At the very least, it suggests that making the case would require substantial departures from the standard gravity-based account typically employed in empirical exercises.

\section{References}

Bahar, Dany (2020). "The hardships of long-distance relationships: time zone proximity and the location of MNC's knowledge-intensive activities," Journal of International Economics. Volume 125, 103311. 
Baldwin, Richard (2019). The Globotics Upheaval: Globalization, Robotics, and the Future of Work. Oxford University Press.

Baldwin, Richard and Daria Taglioni (2006). "Gravity for dummies and dummies for gravity equations," NBER WP 12516, https://www.nber.org/papers/w12516 Eventually published as "Trade effects of the euro: A comparison of estimators", Journal of Economic Integration, 22(4), December, pp 780-818. 2007.

Baldwin, Richard and Rikard Forslid (2019). "Globotics and development: When manufacturing is jobless and services are tradable", CEPR DP 14293.

Bardhan, Ashok Deo, and Cynthia Kroll (2003). "The new wave of outsourcing." UC Berkeley: Fisher Center for Real Estate and Urban Economics.

Barrero, Jose Maria, Nicholas Bloom, and Steven J. Davis (2021). "Why Working From Home Will Stick." Becker Friedman Institute working paper.

Blinder, Alan (2006). Offshoring: The Next Industrial Revolution? March 2006, Foreign Affairs (Council on Foreign Relations) 85(2):113.

Blinder, Alan (2007). "How Many U.S. Jobs Might Be Offshorable?," Princeton University, Center for Economic Policy Studies Working Paper 60.

Blinder, Alan (2009). How Many US Jobs Might be Offshorable? World Economics, 10, issue 2, p. 4178.

Blinder, Alan and Alan Krueger (2013). Alternative Measures of Offshorability - A Survey Approach. Journal of Labour Economics, Journal of Labour Economics, University of Chicago Press, vol. 31(S1), pages S97 - S128.

Caliendo, Lorenzo and Fernando Parro (2015). "Estimates of the Trade and Welfare Effects of NAFTA," Review of Economic Studies, 82(1): 1-44.

Costinot, Arnaud, Dave Donaldson and Ivana Komunjer (2012). "What Goods Do Countries Trade? A Quantitative Exploration of Ricardo's Ideas," Review of Economic Studies, 79(2): 581-608.

Deming, David J (2017). "The growing importance of social skills in the labour market." The Quarterly Journal of Economics 132, no. 4: 1593-1640.

Dingel, Jonathan I. and Brent Neiman (2020). "How Many Jobs Can be Done at Home?", Journal of Public Economics, Volume 189.

Dingel, Jonathan I. and Brent Neiman (2021). "Making a good job of remote work" Financial Times, 7 February 2021. https://www.ft.com/content/b9de71d6-01c8-4de9-80ee-2c756f2f2e99

Dornbusch, Rüdiger, Stanley Fischer, and Paul Samuelson (1977). "Comparative Advantage, Trade, and Payments in a Ricardian Model with a Continuum of Goods", American Economic Review, 67, issue 5, p. 823-39.

Eaton, Jonathan and Samuel Kortum (1999). "International Technology Diffusion: Theory and Measurement," International Economic Review, 40, 537-570.

Eaton, Jonathan and Samuel Kortum (2002). "Technology, Geography, and Trade," Econometrica, Vol. 70, No. 5, pp. 1741-1779.

Fortanier, Fabienne, Antonella Liberatore, Andreas Maurer, Graham Pilgrim, and Laura Thomson (2017). "The OECD-WTO balanced trade in services database." World Trade Organization and Organisation for Economic Co-operation and Development.

Ghemawat, Pankaj (2007). Redefining Global Strategy: Crossing Borders in a World Where Differences Still Matter, Harvard Business School Press. 
ILO (2021). "World Employment and Social Outlook The role of digital labour platforms in transforming the world of work," ILO, Geneva. https://www.ilo.org/wcmsp5/groups/public/--dgreports/---dcomm/---publ/documents/publication/wcms 771749.pdf

Grossman, Gene M. and Esteban Rossi-Hansberg (2008). "Trading Tasks: A Simple Theory of Offshoring," American Economic Review, 98(5): 1978-97.

Head, Keith and Thierry Mayer (2014). "Gravity Equations: Workhorse,Toolkit, and Cookbook." Chapter 3 in Handbook of International Economics, 4: 131-195.

Head, Keith, Thierry Mayer, and John Ries (2009). "How Remote is the Offshoring Threat?" European Economic Review, 53(4): 429-444.

Head, Keith, Thierry Mayer, and John Ries (2010). "The erosion of colonial trade linkages after independence," Journal of International Economics 81(1): 1-14.

ILO (2021). The role of digital labour platforms in transforming the world of work, ILO flagship report, World Employment and Social Outlook 2021, International Labour Organisation, Geneva, https://www.ilo.org/wcmsp5/groups/public/---dgreports/---dcomm/--publ/documents/publication/wcms 771749.pdf

Jensen, J. Bradford, and Lori G. Kletzer (2010). "Measuring tradable services and the task content of offshorable services jobs." In Labour in the new economy, pp. 309-335. University of Chicago Press..

Kehoe, Timothy and Kim Ruhl (2013). "How Important Is the New Goods Margin in International Trade?", Journal of Political Economy, 121(2): 358 - 392.

Kortum, Samuel (1997). "Research, Patenting, and Technological Change," Econometrica, 65, 13891419.

La Porta, Rafael, Florencio Lopez-de-Silanes, and Andrei Shleifer (2008). "The Economic Consequences of Legal Origins." Journal of Economic Literature 46 (2): 285-332.

Liberatore, Antonella, and Steen Wettstein (2021). "The OECD-WTO Balanced Trade In Services Database (BPM6 Edition)."

McKinsey Global Institute (2019). "Globalization in transition: The future of trade and value chains," January.

Nordhaus William D (2008). "Baumol's Diseases: A Macroeconomic Perspective," The B.E. Journal of Macroeconomics, 8(1): 1-39.

O'Connor, Sarah (2020). "If your job can be done from home, can it be offshored somewhere cheaper?", Financial Times, 23 November https://www.ft.com/content/192eb45a-f7c9-4897-ac5657cb743ac2f2

Ricardo, David (1817). On the Principles of Political Economy and Taxation. London: John Murray.

Van Welsum, Desirée and Graham Vickery (2005). "Potential offshoring of ICT-intensive using occupations', DSTI Information Economy Working Paper, OECD, Paris.

Vernon, Raymond (1966). "International Investment and International Trade in the Product Cycle," The Quarterly Journal of Economics, 80, 190-207.

Wessel, David (2004). "The Future of Jobs: New Ones Arise, Wage Gap Widens", The Wall Street Journal, 2 April 2004.

WTO (2019). The future of services trade, World Trade Report 2019, WTO, Geneva.

https://www.wto.org/english/res e/publications e/wtr19 e.htm 